\title{
CARCASS AND BONE CHARACTERISTICS OF BROILER CHICKENS FED DIFFERENT DIETARY FAT SOURCES.
}

\author{
A.I. El-Faham, S.A. Ibrahim, A.D.A. Hemid, F. Abd El-Azeem, M.E. Mohamed and A.M. \\ Tammam
}

Dept. Poult. Prod. Fac. Agric., Ain Shams Univ., Cairo, Egypt

\section{SUMMARY}

\begin{abstract}
$\mathrm{T}$ The aim of this trial was to evaluate the effect of different dietary fat sources on carcass traits, carcass cuts and some bone measurements of broiler chicken. A total of 125, 7 day old (ROSS) broilers were allocated to 5 dietary treatments with 5 replicates ( 5 birds each). Diets were split in phases, a starter (7-21 d), grower (22-28 d) and finisher (29-35 d), where broiler received on out of the experimental diets varying in their fat sources \{Soybean oil (SBO) as control, palm oil (PO) $\mathrm{T}_{1}$, full fat soy (FFS) $\mathrm{T}_{2}$, dry fat (DF) $\mathrm{T}_{3}$ and fatty acid mix (FAM) $\mathrm{T}_{4}$ \} with level of 2,3 and $4 \%$ of starter, grower and finisher diets, respectively. The DF contained (30\% fatty acid $+30 \%$ distillated fatty acid $+40 \%$ wheat bran) while FAM contained ( $50 \%$ fatty acid $+50 \%$ distilled fatty acid). The results showed that: Carcass traits $\%$ (carcass, giblets, total edible parts and abdominal fat) and carcass cuts \% (breast drumstick, thigh and wing) did not significantly differ between treatments. Tibia bone measurements (wet tibia weight, tibia length, tibia breaking strength) showed insignificant difference with dietary treatments. In conclusion, it could be adding PO, FFS, DF or FAM at inclusion rates of $2 \%$ in starter, $3 \%$ in grower and $4 \%$ in finisher broiler diet as a replacement of SBO without any adverse effects on carcass traits or bone measurements.
\end{abstract}

Keywords: Full fat soy, soybean oil, dry fat. fatty acid, broiler and growth performance

\section{INTRODUCTION}

Recently, there has been a significant rise in the price of raw feed materials; also, there is intensive competition between humans and animals on some ingredients as a sources of energy (such as wheat, corn, and some kinds of oils such as soybean oil, corn oil and sunflower oil) Therefore, it is necessary to seek for other alternative sources as untraditional feedstuffs especially in developing country. A considerable attention has been paid to use untraditional fat as a cheap source of energy and protein in poultry diets to achieve a suitable efficiency of utilization and economic efficiency of production.

Little researchers compared between the traditional (commercial) oil/fat sources in poultry diets and the untraditional oil/fat sources (unrefined oil / fat and free and distillated fatty acids released of oil refining process) on broiler performance, and its economic aspects. A considerable attention has been paid to use untraditional fat as a cheap source of energy in poultry diets to achieve a suitable efficiency of utilization and economic efficiency of production. The addition of fat to chicken diets, besides supplying energy improve the absorption of fat soluble vitamins, provides varying quantities of the essential fatty acids, diminishes the dustiness, improves the palatability of the rations by reducing the passage rate of the digested nutrients in the gastrointestinal tract (Baiao and lara ,2005, Nitsan et al., 1997, Moav,1995 and Palmquist, 2002).

Several reports have appeared in the literature that clearly demonstrates that the fatty acid composition of poultry can be markedly altered by type of dietary fat supplement used in broiler diets (Edwards et al., 1971, Pinchasov and Nir, 1992 and Waldroup and Waldroup, 2005). The untraditional fat sources such as, fatty acids, distillated fatty acids, pitch oil and residual oil of commercial plant oil is the most valuable by - product of oil and soap factories. Few investigators used untraditional fat sources in poultry feeding. Ibrahim (2005) reported that sunflower oil, cotton seed oil and distillated fatty acids contained large amount of unsaturated fatty acids, especially linoleic acid (C18:2) (61.44,52.79 and 55.68\%,respectively) compared with palm oil or Nutri fat. However, no significant differences had shown with supplemented different dietary oils on the performance of chicks weight gain, feed intake and feed conversion), or carcass characteristics. Moreover, there were highly significant differences in economic efficiency due to different oils. 
Results concerning of using of various oil/fat sources in diets on broiler performance were varied from study to other. Andreotti et al. (2001) observed that no effects on performance when broilers were fed from 21 to 49 days with diets containing one of the following oil/fat sources included poultry fat, refined soybean oil, refined canola oil, refined sunflower oil, lard and refined corn oil. Lara et al. (2003) fed broilers with different oil/fat sources (degummed soybean oil, poultry fat, acidulated soybean oil soap stock, a mixture of poultry fat/soybean oil and other mixture of soybean oil/ acidulated soybean oil soap stock). They observed better weight gain and feed intake in birds fed with soybean oil in relation to the birds fed with acidulated soybean oil soap stock. Bou et al. (2006) studied the effects of dietary fat sources (beef tallow, fresh sunflower oils, oxidized sunflower oils and linseed oil) on broiler performance. They found that not significant effects among treatments in body weight, body weight gain, feed consumption and feed conversion rate.

Kavouridou et al. (2008) studied effect of different vegetable oil sources (coconut oil, palm oil, olive oil, soybean oil and linseed oil) at $10 \%$ from 30 to 50 days of age and reported that there were no differences among treatments in body weight gain. Velasco et al. (2010) evaluated the effect of adding different types of oil/fat as energy sources on performance. Treatments included 3 concentrations of oil/fat source $(0,5$, and $10 \mathrm{~g} / \mathrm{kg}$ of diet) and 2 types of oil/fat source [palm oil (PO) and sunflower oil (SO)]. Dietary fat type did not affect body weight gain and feed intake but impaired feed conversion in birds fed the PO diets compared with birds fed the SO diets. Mohammadreza et al. (2012) used dietary treatments consisted of $4 \%$ added fat from three different sources (control oil, sunflower oil and tallow) and their combination in broiler diets. Results from the current study suggested that the supplementation with a combination of vegetable and animal fat sources in broiler diet supported positively growth performance.

Nobakht and Mehmannavaz (2012) evaluated the effect of saturated and unsaturated fats in starter and grower feeds on performance broilers. The overall results showed that using $4 \%$ of saturated and unsaturated fat in broiler diets, especially $4 \%$ beef tallow in starter diets and blend of canola oil and beef tallow in grower diets significantly improved the performance of broilers. Kannan et al. (2013) studied the effect of addition of tallow $(2 \%$ and $4 \%)$ and sunflower oil $(2 \%$ and $4 \%)$ either alone or in combination of (SF oil 1\% + tallow $1 \%$ and SF oil $2 \%+$ tallow $2 \%$ ) on broiler performance. They found that the lipid source (sunflower oil or tallow) and their combinations had not affected on the growth rate, feed consumption and feed efficiency in broilers chickens at 49 day of age.

This study aimed to investigate the effect of some untraditional oil/fat sources, which produced as byproducts of oil refining process in broiler diets on carcass traits and bone measurements at different fattening periods or overall period.

\section{MATERIALS AND METHODS}

The present study was carried out at the Poultry Nutrition Farm, Poultry Production Department, Faculty of Agriculture, Ain Shams University, Shoubra El-kheima, Kaliobia, Egypt. This study aimed to investigate the effect of using some untraditional feedstuffs as source of energy in broiler diets.

\section{Experimental design}

\section{Birds housing and management}

125 unsexed day-old of ROSS broiler chicks were used in this study; obtained from a commercial hatchery and randomly distributed in to 5 treatments. Each treatment comprised of 25 chicks divided into five replicates of five chicks.

\section{Experimental diets}

Table (1) showed the composition and calculated analysis of experimental diets. Three periodical diets were formulated in experiment includes, starter from 7 to 21 days of age, grower from 22 to 28 days of age and finisher from 29 to 35 day -old. The nutrient requirements were supplied to according (CLFF, 2001).

The tested oil/fat treatments were soybean oil (SBO) as a control treatment, palm oil (PO, $\left.\mathrm{T}_{1}\right)$, full fat soy (FFS, $\mathrm{T}_{2}$ ), dry fat (DF, $\mathrm{T}_{3}$ ) and Fatty acid mix (FAM, $\mathrm{T}_{4}$ ) with levels of 2,3 and $4 \%$ of starter, grower and finisher diets, respectively. The dry fat contained $30 \%$ fatty acid, $30 \%$ distillated fatty acid and $40 \%$ wheat bran as a carrier. The Fatty acid mix ( $50 \%$ fatty acid: $50 \%$ distillated fatty acid). Chicks were fed a 
commercial starter diet containing 23\% CP and $3025 \mathrm{ME} / \mathrm{Kg}$ during the first week of age before receiving the formulated experimental diets to minimize the maternal effect.

\section{Measurements:}

At 35 day of age, 3 chicken close to mean live body weight (LBW) were selected from each replicate for slaughter procedure. Liver, gizzard, heart and carcass cuts (breast, drumstick, thigh and wing) and abdominal fat have recorded and express as relative to LBW at processing. Right tibia has removed and cleaned from soft tissues then weighted. Length and diameter of tibia were measured using a digital caliper tibia seedor index were calculated according to seedor et al. (1991).

\section{Data and Statistical analysis.}

Statistical analysis of both experiments was conducted using the general linear model (GLM) procedure of base SAS ${ }^{\circledR}$ (SAS instituted, 1995). Factors test using one way ANOVA. Means were compared using Duncan's range test (Duncan, 1955) where the level of significance was set at minimum $(\mathrm{P} \leq 0.05)$.

Dietary treatments were assigned as the main factor, the statistical model performed as fallow:

$$
\mathrm{Y}_{\mathrm{ij}}=_{\mathrm{u}}+\mathrm{T}_{\mathrm{i}}+\mathrm{E}_{\mathrm{ij}}
$$

Where $Y_{i j}=$ is the effect of the observation, $u=$ overall mean, $T_{i}=$ the effect of $i^{\text {th }}$ dietary treatments and $E_{i j}$ $=$ random error.

Table (1): Composition and calculated analysis of experimental starter, grower and finisher diets.

\begin{tabular}{|c|c|c|c|}
\hline Ingredients $(\%)$ & $\begin{array}{l}\text { Starter } \\
7-21 \text { day }\end{array}$ & $\begin{array}{l}\text { Grower } \\
22-28 \text { day }\end{array}$ & $\begin{array}{l}\text { Finisher } \\
29-35 \text { day }\end{array}$ \\
\hline Yellow corn & 55.6 & 59.47 & 63.41 \\
\hline Soybean meal $48 \%$ & 38.5 & 33.70 & 29.10 \\
\hline *Soy bean oil & 2.00 & 3.00 & 4.00 \\
\hline Bone meal & 3.00 & 2.60 & 2.30 \\
\hline Limestone & 0.20 & 0.50 & 0.45 \\
\hline Natural salt & 0.30 & 0.30 & 0.30 \\
\hline **Vit+Min Premix & 0.30 & 0.30 & 0.30 \\
\hline DL - methionine & 0.10 & 0.13 & 0.14 \\
\hline Total & 100.00 & 100.00 & 100.00 \\
\hline Calculated analysis: & & & \\
\hline Crude protein $(\%)$ & 22.99 & 20.96 & 19.02 \\
\hline $\mathrm{ME}(\mathrm{kcal} / \mathrm{kg})$ & 2970 & 3066 & 3169 \\
\hline Calcium $(\%)$ & 1.01 & 1.00 & 0.89 \\
\hline $\begin{array}{l}\text { Available phosphorus } \\
(\%)\end{array}$ & 0.50 & 0.45 & 0.41 \\
\hline Methionine (\%) & 0.52 & 0.52 & 0.51 \\
\hline $\begin{array}{l}\text { Methionine + } \\
\text { Cysteine }(\%)\end{array}$ & 0.85 & 0.82 & 0.78 \\
\hline Lysine $(\%)$ & 1.37 & 1.23 & 1.1 \\
\hline Stearic C18:0 & 0.08 & 0.13 & 0.17 \\
\hline Oleic C18:1 & 0.58 & 0.88 & 1.17 \\
\hline Linoleic C18:2 & 1.23 & 1.85 & 2.49 \\
\hline
\end{tabular}

*Soy bean oil (SBO) replaced by Palm oil, Full fat soya, Dry fat or Mix fatty acid

**Composition of vitamin and minerals premix. Each $3 \mathrm{~kg}$ of premix containing: 15000000 I.U VIT. A, $50 \mathrm{~g}$. VIT.E, $3000 \mathrm{mg}$. VIT.K3, $3000 \mathrm{mg}$.VIT.B1, $8000 \mathrm{mg}$. VIT.B2, $4000 \mathrm{mg}$.VIT.B6, $20 \mathrm{mg}$. VIT. B12, $15000 \mathrm{mg}$. Pantothenic acid, $60000 \mathrm{mg}$. Niacin, $1500 \mathrm{mg}$. Folic acid, $200 \mathrm{mg}$. Biotin, $200000 \mathrm{mg}$ gm. vit C, $700 \mathrm{gm}$. Choline chloride, 80 $\mathrm{Mn}, 80 \mathrm{gm}$. Zn, $60 \mathrm{gm}$. Iron, $10 \mathrm{gm}$. Cu, $1 \mathrm{gm}$. Iodine, and $0.2 \mathrm{gm}$. Selenium, where CaCo3 was taken as a carrier up to $3 \mathrm{~kg}$, the inclusion rate was $3 \mathrm{~kg}$ premix / Ton feed.

*** Calculated analysis of the experimental diets done according to (CLFF, 2001). 


\section{RESULTS AND DISSCUSION}

\section{Carcass characteristics}

Data in Table (2) summarized the effect of feeding the experimental diets containing different fat sources on carcass characteristics of broiler chicks at 35 days old age. Experimental treatment with different fat sources had no significant effect on different parameters compared with control. The corresponding values for carcass \% ranged between 75.02 and $71.07 \%$ while total edible parts (carcass + giblets) percentages ranged between 78.57 and $74.84 \%$ abdominal fat $\%$ ranged between 1.81 and $1.52 \%$. On the other hand, the chicks fed DF $\left(\mathrm{T}_{3}\right)$ gave the lowest figures of 71.06 and $74.84 \%$ for dressing and insignificant differences compared with other treatments.

\section{Carcass cuts\%}

As shown in Table (2) no significantly $(\mathrm{P}>0.05)$ differences were observed in percentages of breast, thigh drumstick and wing between treatments. However the birds fed diets containing DF, SBO and PO had the highest percentages of breast $(34.75,34.61$ and $34.01 \%$, respectively) compared with other treatments and birds fed diets containing FFS and FAM had the lowest percentage of breast (32.22 and $32.14 \%$, respectively) and bird fed diet containing FFS had the highest percentage of drumstick $(10.35 \%)$ compared with other treatments while birds fed diets containing DF had the lowest percentage of drumstick $(9.55 \%)$. Birds fed diet containing PO had the highest percentage of thigh $(19.09 \%)$ compared with other treatments and birds fed diets containing FAM had the lowest percentage of thigh (16.22).Birds fed diet containing FFS had the highest percentage of wing (6.97\%) compared with other treatments and birds fed diets containing FAM had the lowest percentage of wing (6.43). Similar observation were reported by Sanz et al. (1999), Rondelli et al. (2004), Firman et al. (2008), Guerreiro et al. (2011), Habib et al. (2011),Nobakht et al. (2011) and Lara et al. (2006) who evaluated the effect of different fat and oil sources of diets (soybean oil, poultry fat, acidulated soybean oil soap stock and a mix of soybean oil plus poultry fat and soybean oil plus acidulated soybean oil soap stock) on carcass yield, composition of the breast, thigh and whole chickens and fatty acid profile of the whole carcass of broilers. No effects of fat source were observed on carcass yield and cuts.

However, Alizadeh et al. (2012), Mohammadreza et al. (2012) and Moraes et al. (2009) who compared between different oil/fat sources (soybean oil (SO) and semi-refined rice oil (RBO) added to broilers diets to study the effect of different oil/fat sources on broiler performance. Experiment was contained conducted using two types of oils (SO or RBO) and four oil levels (1\%, 2.5\%, 4\%, or 5.5\%, respectively). Oil inclusion level negatively affected breast yield.

\section{Bone traits}

As shown in Table (3) no significant $(\mathrm{P}>0.05)$ differences were observed in the values of tibia wet weight, dry tibia weight, tibia length, tibia width, seedor index and tibia breaking strength between treatments. However the birds fed diet containing SBO had the highest value of tibia wet weight $(12.08 \mathrm{~g})$ compared with other treatments and birds fed diets containing DF had the lowest values of tibia wet weight $(10.12 \mathrm{~g})$. Birds fed diet containing FFS had the highest value of dry tibia weight $(5.57 \mathrm{~g})$ compared with other treatments and birds fed diets containing DF had value of dry tibia weight (4.99 $\mathrm{g})$. Birds fed diet containing PO had the highest value of tibia length $(8.93 \mathrm{~mm})$ compared with other treatments and birds fed diets containing DF had the lowest value of tibia length $(8.56 \mathrm{~mm})$. Birds fed diets containing FAM had the highest values of tibia width, seedor index and tibia breaking strength (TBS) $(0.85,0.62$ and 31.0 respectively) compared with SBO treatments $(0.85,0.59$ and 26.66 respectively).

\section{CONCLUSION}

In this study, we concluded that different dietary fat/oil sources (palm oil, full fat soy, dry fat and fatty acid mix) at level 2,3 and $4 \%$ in starter, grower and finisher diets can be fed to broiler chicks without unfavorable effect on carcass traits or bone measurements. 
Table (2): Effect of different dietary treatments on carcass characteristics and carcass parts as a \% of live body weight of broiler chickens at 35 day-old.

\begin{tabular}{lccccccc}
\hline & \multicolumn{9}{c}{ Treatment } & & \\
\cline { 2 - 5 } Item & Co & T1 & T2 & T3 & T4 & \multirow{2}{*}{ S.E } & Sig \\
\hline Carcass characteristics \% & SBO & PO & FFS & DF & FAM & & \\
Carcass & 71.90 & 75.02 & 71.57 & 71.06 & 72.16 & \pm 0.76 & NS \\
Liver & 1.97 & 1.93 & 1.81 & 2.06 & 1.65 & \pm 0.22 & NS \\
Gizzard & 1.15 & 1.10 & 1.15 & 1.21 & 1.31 & \pm 0.08 & NS \\
Heart & 0.55 & 0.51 & 0.51 & 0.51 & 0.46 & \pm 0.04 & NS \\
Giblets & 3.69 & 3.55 & 3.49 & 3.78 & 3.43 & \pm 0.26 & NS \\
Total edible parts & 75.60 & 78.57 & 75.07 & 74.84 & 75.59 & \pm 0.84 & NS \\
Abdominal fat & 1.64 & 1.60 & 1.52 & 1.68 & 1.81 & \pm 0.25 & NS \\
\hline Carcass cuts \% & & & & & & & \\
Breast & 34.63 & 34.01 & 32.22 & 34.75 & 32.14 & \pm 1.32 & NS \\
Drumstick & 9.86 & 10.27 & 10.35 & 9.55 & 9.84 & \pm 0.39 & NS \\
Thigh & 17.23 & 19.09 & 17.64 & 17.22 & 16.22 & \pm 1.30 & NS \\
Wing & 6.50 & 6.64 & 6.97 & 6.61 & 6.43 & \pm 0.27 & NS \\
\hline
\end{tabular}

Means within the some row with different superscripts are significantly different.

Sig=Significance $* *(P \leq 0.01), *(P \leq 0.05) . N S=$ Non Significance.

$*$ Total edible parts $=$ carcass $\%+$ giblets $\%($ Liver $\%+$ Gizzard $\%+$ Heart $\%)$

Table (3): Effect of different dietary treatments on some bone traits of broiler chickens at 35 day-old.

\begin{tabular}{lccccccc}
\hline & \multicolumn{7}{c}{ Treatments } \\
\hline \multirow{2}{*}{ Item } & Co & T1 & T2 & T3 & T4 & \multirow{2}{*}{ S.E } & Sig \\
\hline Wet Tibia Weight $(\mathrm{g})$ & SBO & PO & FFS & DF & FAM & & NS \\
Dry Tibia Weight (g) & 12.08 & 10.42 & 10.59 & 10.12 & 10.95 & \pm 0.86 & NS \\
Tibia length (mm) & 5.19 & 5.33 & 5.57 & 4.99 & 5.47 & \pm 0.28 & NS \\
Tibia Width (mm) & 8.73 & 8.93 & 8.89 & 8.56 & 8.79 & \pm 0.09 & NS \\
Seedor index & 0.82 & 0.75 & 0.77 & 0.78 & 0.85 & \pm 0.02 & NS \\
Tibia Breaking & 0.59 & 0.59 & 0.62 & 0.58 & 0.62 & \pm 0.02 & \multirow{2}{*}{ NS } \\
Strength $\left(\mathrm{Kg} / \mathrm{cm}^{2}\right)$ & 26.66 & 27.33 & 28.66 & 30.33 & 31.00 & \pm 2.66 & \\
\hline
\end{tabular}

Strength $\left(\mathrm{Kg} / \mathrm{cm}^{2}\right)$

Means within the some row with different superscripts are significantly different.

Sig=Significance ${ }^{* *}(P \leq 0.01), *(P \leq 0.05) . N S=$ Non Significance.

\section{REFRANCES}

Alizadeh S., M.H. Shahir, H. Amanlo, N. Baradaran and Z. AsadiKermani (2012). Sunflower oil production wastes (acidulated soap stock) as an energy source in broiler chickens diet. the International and The 4th National Congress on Recycling of Organic Waste in Agriculture, Isfahan, Iran.

Andreotti M.O., O.M. Junqueira, L.C. Cancherini, E.A. Rodrigues, N.K. Sakomura (2001). Valor nutricional de algumasfontes de gordura para frangos de corte. In: Anais da $38^{\circ}$ ReuniãoAnual da SociedadeBrasileira de Zootecnia; 2001; Piracicaba, SP. Piracicaba: SBZ.

Baião, N.C. and L.J.C Lara. (2005). Oil and fat in broiler nutrition. Braz. J. Poult. Sci., 7: 129-141.

Bou R., S. Grimpa, F. Guardiola, A.C. Barroeta, and R. Codony (2006). Effects of various fat sources, $\alpha-$ tocopheryl acetate, and ascorbic acid supplements on fatty acid composition and $\alpha$-tocopherol containingin raw and vacuum-packed, cooked dark chickens meat. Poult. Sci., 85:1472-1481.

Edwards H.M., T.M. Huston, A. Abou Ashour and D.Nugara (1971). Factors influencing the lipid and fatty acid composition of broilers. Pages 63-70 in: Proc. Maryland Nutr. Conf., Washington DC. 
GuerreiroNeto A.C., A.C. Pezzato, J.R. Sartori, C. Mori, V.C. Cruz, V.B. Fascina, D.F. Pinheiro, L.A. Madeira, J.C. Gonçalvez (2011). Emulsifier in broiler diets containing different fat sources. Rev. Bras. Cienc. Avic. vol.13 no.2 Campinas Mar./June .

Shahryar H.A., R.S. Nobar, A. Lak and A. Lotfi (2011). Effect of dietary supplemented canola oil and poultry fat on the performance and carcass characterizes of broiler chickens. Current Research Journal of Biological Sciences, 3(4): 388-392.

Ibrahim. S.A. (2005). Effect of different dietary oils on the performance of silver Montazah growing chicks. J. Agric. Sci. Mansoura., 30(8): 4439-4449.

Jeffre D. Firman, A. Kamyab and H. Leigh. (2008). Comparison of fat sources in rations of broilers from hatch to market. International J. of Poult. Sci., 7 (12): 1152-1155.

Kannan D., M. Senthilkumar and K. Mani (2013). Effect of saturated and unsaturated fat on the performance, serum and meat cholesterol level in broilers. doi:10.5455/vetworld.2013.159-162

Kavouridou K., A.C. Barroeta, C. Villaverde, E.G. Manzanilla and M.D. Baucells (2008). Fatty acid, protein and energy gain of broilers fed different dietary vegetable oils. Spanish J. of Agricultural Research, 6(2): 210-218.

Lara L.J.C., N.C. Baião, C.A.A. López, B.H.S. Moura, B.R.C. Ribeiro (2003). Fuentes de aceiteen la ración de pollos de carne. In: XVIII CongressoLatinoamericano de Avicultura; Santa Cruz De La Sierra, Bolívia. CD-ROM.

Moav, R. (1995). Fat supplementation to poultry diet. Wrld Poult. Misset., 11: 57-58.

MohammadrezaPoorghasemiAlirezaSeidavi Ali Ahmad AlawQotbi Vito Laudadiol and Vincenzo Tufarelli1. (2012). Influence of dietary fat source on growth performance responses and carcass traits of broiler chicks. Asian Australas. J. Anim. Sci., 26(5): 705-710.

Moraes M.L., A.M.L. Ribeiro, A.deM. Kessler, M.M. Cortés, V.S. Ledur and E. Cura (2009). Comparison of the effects of semi-refined rice oil and soybean oil on meat oxidative stability, carcass yield, metabolism, and performance of broilers. Rev. Bras. Cienc. Avic. vol.11 no.3 Campinas July/Sept.

Nitsan, Z., A. Dvorin, Z. Zoref, and S. Mokady. (1997). Effect of added soybean oil and dietary energy on metabolizable and net energy of broiler diets. Br. Poult. Sci., 38: 101-106.

Nobakht A., A. Mehmannavaz (2012). Effects of saturated and unsaturated fats in starter and grower feeds on performance and carcass traits of broilers. J. Basic. Appl. Sci. Res., 2(2):967-970.

Palmquist, D.L. (2002). An appraisal of fats and fatty acid. In: Poultry Feedstuff: Supply, Composition and Nutritive Value. Chapter 5, pp. 87-97.

Pinchasov,Y. and I. Nir (1992). Effect of dietary polyunsaturated fatty acid concentration on performance, fat deposition and carcass fatty acid composition in broiler chicken. Poult. Sci., 71: 1504-1512.

Rondelli S.G., O. Martinez and P.T. García (2004). Effects of different dietary lipids on the fatty acid composition of broiler abdominal fat. Rev. Bras. Cienc. Avic. vol.6 no.3 Campinas July/Sept.

Sanz M., A. Flores and C.J. Lopez-Bote (1999). Effect of fatty acid saturation in broiler diets on abdominal fat and breast muscle fatty acid composition and susceptibility to lipid oxidation. Poult. Sci., 78: 378-382.

Velasco S., L.T. Ortiz, C. Alzueta, A. Rebole, J. Trevino, and M.L. Rodriguez (2010). Effect of inulin supplementation and dietary fat source on performance, blood serum metabolites, liver lipids, abdominal fat deposition, and tissue fatty acid composition in broiler chickens. Poult. Sci., 89: 16511662.

Waldroup P.W. and A.L. Waldroup (2005). Fatty acid effect on carcass: The Influence of various blends of dietary fats added to corn-soybean meal based diets on the fatty acid composition of broilers. Inter. J. of Poult. Sci., 4(3):123-132. 


\title{
صفات الأبيحة ومقاييس العظم لاجاج اللحم المغذى على مصادر مختلفة من الدهون.
}

\author{
أحمد ابراهيم الفحام وسيد عبد الرحمن ابراهيم وعلاء الاين عبد السلام حميد وفتحي عبد العظيم محمد ومحمد مصطفي \\ السيا وأحمد محمد تمام \\ قسم انتاج الدواجن ـ كلية الزراعة - جامعة عين شعس - مصر
}

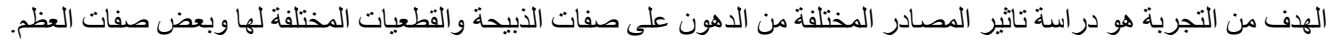

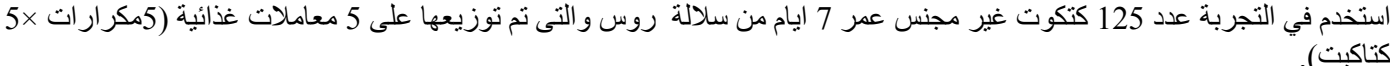

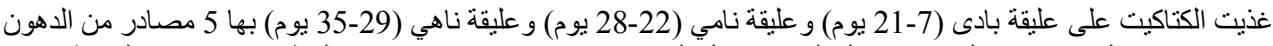

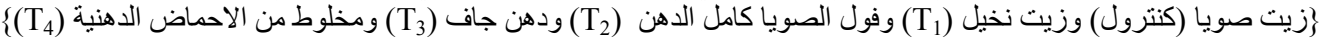

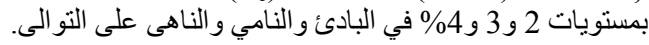

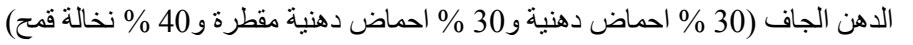
مخلوط احماض دهنية (50 \% الحماض دهنية و 50 \% احماض دهنة دهنية مقطرة) اهم النتائج لم تلتاثر صفات الذبيحة \% (الذبيحة و الحو ائج و الاجز اء الكلية الماكولة ودهن البطن وكذللك القطعيات المختلفة ( صدر الفخذ

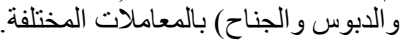
لم تتأثر صفات عظمة الساق( وزن جاف ورطب وطنات وطول وقوة كسر ) بالمعاملات الغذائية.

الخلاصة: يكن استخدام زيت النخيل وفول الصويا كامل الدهن ودهن الجاف ومخلوط الاحماض الدهنية بمستوى 2\% بادى و3\% نامى و4 \% ناهى لعلائق بداري التسمين بديلا لزيت فول الصويا بدون اي تاثير ضار على على صفات الذبيحة ومقاييس العظم. 